\title{
PENGEMBANGAN MEDIA PEMBELAJARAN TOLAK PELURU
}

\author{
Penulis
}

\author{
RINDI SRI UTAMI \\ NPM. 14.85201.0046 \\ PROGRAM STUDI PENDIDIKAN JASMANI \\ STKIP PGRI TRENGGALEK
}

Alamat: JL. Supriyadi 22 KP. 66319Telp./Fax. (0355) 791551 Trenggalek

Jawa Timur - Indonesia

E-mail : stkiptrenggalek@yahoo.co.id

\begin{abstract}
Abstrak: Penelitian ini bertujuan untuk membantu siswa yang mengalami kesulitan pada pembelajaran atletik nomor tolak peluru karena keterbatasan media pembelajaran tolak peluru. Penelitian ini menggunakan metode penelitian dan pengembangan (R\&D). Pada penelitian ini menggunakan prosedur penelitian dengan model pengembangan ADDIE: Analysis, Design, Development, Implementation, Evaluation. Proses penilaian desain produk melibatkan ahli pembelajaran atletik dan ahli media pembelajaran. Pengujian media pembelajaran diberikan pada perwakilan siswa kelas VII SMP Negeri 1 Tugu dengan sampel uji coba kelompok kecil 14 siswa dan uji coba kelompok besar 28 siswa. Berdasarkan penelitian ini diperoleh hasil bahwa pengembangan media pembelajaran tolak peluru dapat digunakan sebagai alternatif media pembelajaran tolak peluru. Hal ini diperoleh dari hasil penelitian dengan persentase nilai dari hasil uji coba kelompok kecil dengan nilai rata-rata $82 \%$ (kategori baik) dapat digunakan dan dari hasil uji coba kelompok besar dengan nilai rata-rata 82,71\% (kategori baik) dapat digunakan.
\end{abstract}

\section{Kata Kunci: Atletik; Media Pembelajaran; Pengembangan; Tolak Peluru}

\begin{abstract}
This research aims to help student who have difficulty in learning athletic number by a shot put because of the limitation of learning media. This research uses research and development method (R\&D). This research used ADDIE development model: Analysis, Design, Development, Implementation, Evaluation. The product design assessment process involves athletic learning experts and learning media specialists. Testing of intructional media given to representatives of seven class student of SMP Negeri 1 Tugu with sample of small group trial 14 student and large group trial 28 student. Based on this research the development of learning media using can be use as shot put can be used as an alternative to learning media to the shot put. This is obtained from the result of the research with a percentage of the value of the result of small group trial result with an avarage value of $82 \%$ (good category) and large group trial result with an avarage value of $82,71 \%$ (good category).
\end{abstract}

Keywords: Athletic; Learning Media; Development; Shot put 


\section{PENDAHULUAN}

Pendidikan sekolah sangat penting untuk menciptakan sumber daya manusia yang berguna bagi bangsa, negara, dan hidup bermasyarakat di Indonesia ini. Pendidikan merupakan suatu aspek yang tidak pernah lepas dari kehidupan manusia (Putro, 2016). Menurut UU RI No. 20 Tahun 2003 Pasal 40 Ayat 2a, menyatakan bahwa tujuan dari Pendidikan Nasional adalah pendidikan dan tenaga kependidikan berkewajiban menciptakan suasana yang bermakna, menyenangkan, kreatif dan dinamis. Pendidikan jasmani pada dasarnya merupakan bagian integral dari sistem pendidikan secara keseluruhan, yang bertujuan untuk mengembangkan aspek kesehatan, kebugaran jasmani, ketrampilan berfikir kritis, stabilitas emosional, ketrampilan sosial, penalaran, dan tindakan moral melalui aktivitas jasmani dan olahraga. (Wiarto, 2015) Dari uraian di atas dapat disimpulkan bahwa dalam proses pembelajaran pendidikan jasmani siswa dapat menghasilkan suatu perubahan yang bertahap dalam dirinya, baik dalam bidang pengetahuan, keterampilan, dan sikap. Adapun tujuan dalam pembelajaran pendidikan jasmani dan olahraga untuk mengarahkan siswa agar dapat beraktivitas olahraga, sehingga tercipta generasi yang sehat dan kuat. Pembelajaran pendidikan jasmani dan olahraga mengupayakan untuk meningkatkan kemampuan gerak dasar anak. Dalam pembelajaran pendidikan jasmani dan olahraga bagi siswa sekolah hendaknya harus disesuaikan dengan karakteristik dan perkembangannya agar kemampuan gerak dasarnya berkembang dengan baik. Pendidikan jasmani, olahraga dan kesehatan menaruh perhatian lebih dalam

pengembangan aspek psikomotorik (Putro, 2016) Komponen-komponen kemampuan gerak dasar yang meliputi: gerak stabilitas, gerak lokomotor dan gerak manipulatif harus dikembangkan dengan bentuk pembelajaran pendidikan jasmani dan olahraga yang tepat.

Namun pada kenyataanya aktivitas pembelajaran penjasorkes di sekolah sering kali terhambat dengan sarana dan prasarana yang ada, jika sarana dan prasarana yang ada di sekolah tidak memadai maka guru enggan melakukan modifikasi. Guru lebih suka mempraktekkan pembelajaran sesuai dengan sarana dan prasarana yang ada di sekolah, jika sarana dan prasarana tidak memadai maka guru hanya mengajarkan teorinya saja yang berakibat siswa tidak bisa melakukan praktek dengan teknik yang baik dan benar. Permasalan ini dialami oleh siswa SMP Negeri 1 Tugu pada pembelajaran atletik nomor tolak peluru. Di SMP Negeri 1 Tugu untuk jumlah peluru yang ada tidak mencukupi untuk melaksanakan pembelajaran yang ideal. Kendala ini bisa dilihat dari sekian banyak siswa yakni dari kelas VII sampai dengan kelas IX yang berjumlah 600 siswa hanya mempunyai 6 
buah peluru yakni 3 buah peluru untuk kategori putra dan 3 buah peluru untuk kategori putri.

Akibat dari keterbatasan media pembelajaran tolak peluru siswa di SMP Negeri 1 Tugu jarang melaksanakan praktek pembelajaran atletik nomor tolak peluru karena pembelajaran tidak maksimal. Untuk mengatasi permasalahan yang ada dalam pembelajaran atletik nomor tolak peluru maka seorang guru harus mampu mencarikan solusi yang tepat agar tujuan pembelajaran pendidikan jasmani dan olahraga tercapai. Modifikasi media pembelajaran pendidikan jasmani dan olahraga merupakan salah satu solusi untuk mengatasi masalah yang dihadapi siswa di SMP Negeri 1 Tugu pada pembelajaran atletik nomor tolak peluru. Tolak peluru adalah jenis olahraga yang cara melakukannya dengan cara di dorong atau menolak dan bukan melempar yang bertujuan untuk mendapatkan jarak yang sejauhjauhnya dan untuk ukuran berat peluru dibedakan berdasarkan kriteria umur. Untuk ukuran kategori berat peluru yang digunakan dalam tolak peluru adalah sebagai berikut: (1) Senior Putra; 7,257 kg (2) Senior Putri; 4 kg (3) Yunior Putra; 5 kg (4) Yunior Putri; 3 kg. (Pardijono dan Yulfadinata, 2014)

Dengan adanya permasalahan ini peneliti berinisiatif mengembangkan media pembelajaran tolak peluru yang lebih ringan dan disesuaikan dengan kenyamanan siswa. Tujuan dari pengembangan media pembelajaran tolak peluru ini bisa mempermudah siswa dalam melaksanakan kegiatan pembelajaran tolak peluru sehingga diharapkan dalam pengembangan media pembelajaran tolak peluru ini siswa tetap bisa melaksanakan pembelajaran tolak peluru dengan teknik yang baik dan benar. Penelitian ini akan membuat sebuah produk pengembangan media pembelajaran tolak peluru yang dijadikan sebagai alternatif media pembelajaran tolak peluru. Spesifikasi produk yang dikembangkan, diantaranya: (1) Lebih ringan dengan 450 gram, (2) Diameter peluru $11 \mathrm{~cm}$, (3) Mudah dibuat dan bahan mudah didapat, (4) Pembuatan produk relatif singkat, (5) Tidak memerlukan biaya yang banyak, (6) Mudah digunakan, (7) Tidak terlalu berat bagi siswa SMP, (8) Tingkat cedera rendah (9) Produk yang dihasilkan bulat. Berikut ini alur karangka berpikir yang digunakan untuk menggambarkan pemikiran pengembang berdasarkan dari teori yang ditetapkan oleh peneliti:

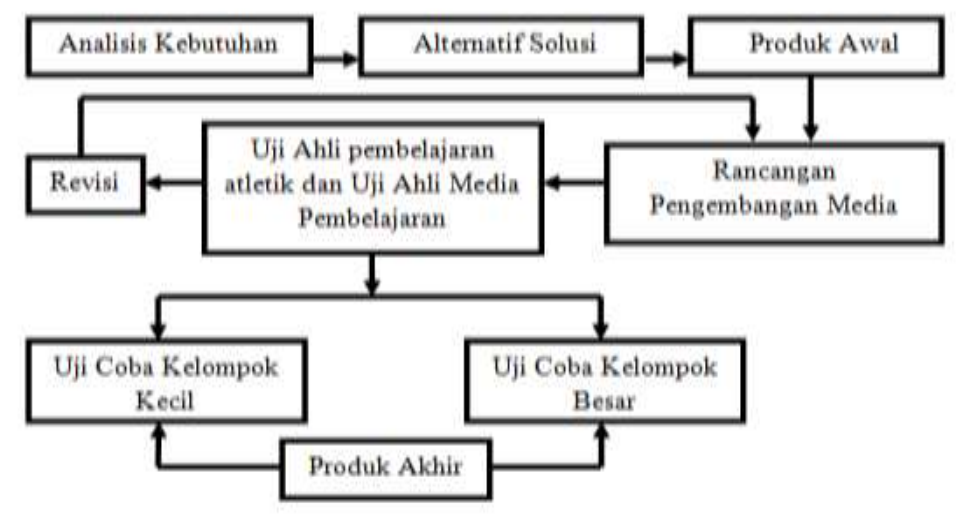


Gambar

Bagan Karangka Berpikir

Rancangan model produk pengembangan media pembelajaran tolak peluru ini berbeda dari pengembangan produk yang sebelumnya. Pada produk pengembangan sebelumnya berat dan diameter tidak konsisten, serbuk gergaji yang digunakan serbuk gergaji yang kasar (limbah mebel), serta untuk hasil produk yang dimodifikasi tidak berbentuk bulat masih ada tonjolan di ujungnya yang mengakibatkan pada saat menggenggam peluru kesulitan. Untuk rancangan model yang sekarang dalam pembuatan produk berat dan diameter konsisten, serbuk gergaji yang digunakan serbuk gergaji yang halus (limbah pemotongan kayu), hasil produk bulat sehingga pada saat menggenggam peluru tidak kesulitan.

\section{METODE PENELITIAN}

Penelitian ini merupakan penelitian dan pengembangan (Research and Development). Menurut Sugiyono (2011) metode penelitian dan pengembangan (Research and Development) adalah metode penelitian yang digunakan untuk menghasilkan sebuah produk. Penelitian dan pengembangan (Research and Development) tidak dimaksudkan untuk menguji atau menerapkan teori, akan tetapi merupakan penelitian yang berorientasi untuk menghasilkan atau mengembangkan produk yang dapat langsung segera dimanfaatkan. Pada penelitian ini menggunakan prosedur penelitian ADDIE. Menurut Branch (2009), model pengembangan ADDIE adalah salah satu model desain sistem pembelajaran yang memperlihatkan tahapan-tahapan dasar untuk mengembangkan dan memvalidasi produk-produk yang digunakan dalam pendidikan. ADDIE adalah singkatan dari Analysis - Design - Development - Implementation - Evaluation). Dalam prosedur ataumodel penelitian ini ada lima kegiatan atau tahapan, diantaranya: (1) Analisis (Analysis); Pada tahap ini kegiatan utama adalah menganalisis perlunya pengembangan media pembelajaran dan menganalisis kelayakan dan syarat-syarat pengembangan media pembelajaran. Pengembangan media pembelajaran diawali dengan adanya masalah dalam media pembelajaran yang sudah diterapkan. Dalam hal ini peneliti melakukan observasi dan 
melakukan wawancara kepada guru penjasorkes mengenai pembelajaran tolak peluru, serta melihat sarana dan prasarana untuk cabang olahraga atletik nomor tolak peluru yang ada di SMP Negeri 1 Tugu. (2) Desain (Design); Dalam perancangan media pembelajaran, tahap desain memiliki kemiripan dengan merancang kegiatan belajar mengajar. Berdasarkan hasil observasi dan wawancara yang telah dilakukan untuk mengatasi masalah atau kendala yang ada untuk cabang olahraga atletik nomor tolak peluru, maka peneliti mencari solusi agar pembelajaran pendidikan jasmani dan olahraga tetap terlaksana, yaitu dengan cara membuat desain pengembangan media pembelajaran tolak peluru sehingga dapat dijadikan sebagai alternatif media pembelajarana tolak peluru. (3) Pengembangan (Development); Pada tahap pengembangan berisi kegiatan realisasi rancangan produk yang masih konseptual direalisasikan menjadi produk yang siap diimplementasikan. Setelah desain produk jadi sebelum di ujikan peneliti melakukan validasi kepada ahli pembelajaran atletik dan ahli media pembelajaran dengan cara memberikan angket semi terbuka. Selanjutnya apabila mendapat saran dari para ahli maka peneliti melakukan revisi produk agar lebih sempurna sesuai saran dan masukan para ahli. (4) Penerapan (Implementation); Pada tahap ini peneliti menerapkan produk yang telah dikembangkan pada situasi yang nyata pada uji coba kelompok kecil dan uji coba kelompok besar, untuk uji coba kelompok kecil dilakukan kepada perwakilan dari siswa kelas VII SMP Negeri 1 Tugu sebanyak 14 siswa serta uji coba kelompok besar dilakukan kepada perwakilan dari siswa kelas VII SMP Negeri 1 Tugu sebanyak 28 siswa. (5) Evaluasi (Evaluation); Tahap evaluasi merupakan tahapan akhir dari sebuah penelitian. Dari hasil uji coba akhir yang berupa angket terbuka, maka peneliti mengetahui seberapa besar persentase keberhasilan pengembangan media pembelajaran tolak peluru kemudian membuat kesimpulan berdasarkan hasil penelitian. Apakah pengembangan media pembelajaran tolak peluru sudah berhasil sesuai dengan harapan peneliti dan dapat dijadikan sebagai alternatif media pembelajaran tolak peluru.

Populasi yang terlibat dalam proses penelitian ini adalah seluruh siswa kelas VII yang berjumlah 220 siswa dan sampel yang terlibat dalam proses penelitian ini adalah perwakilan kelas yang berjumlah 42 siswa. Teknik pengambilan sampel yang digunakan adalah quota sampling untuk menentukan jumlah sampel uji coba kelompok kecil berjumlah 14 subjek penelitian serta jumlah sampel uji coba kelompok besar berjumlah 28 subjek penelitian. Selanjutnya menggunakan teknik simple random sampling dengan kelas sebagai unitnya yaitu sebanyak 7 kelas (A, B, C, D, E, F, G) kemudian di pilih secara acak per kelasnya dengan cara undian, teknik undian dilakukan dengan cara: (1) Membuat potongan kertas yang diberi nomor sesuai dengan absen per kelas, (2) Kertas dilipat dan dimasukkan ke 
dalam kotak atau gelas yang diberi lubang kecil di penutupnya, (3) Kotak atau gelas dikocok, lalu diambil satu potong setiap kali pengocokan, (4) Angka atau nomor yang tertera dalam kertas tersebut dilihat dan dicatat angkanya sampai dengan pengocokan jumlah sampel yang diinginkan. Misalnya yang terambil adalah angka 15, maka sampel yang terpilih adalah nomor 15. Metode pengumpulan data dan instrumen pengumpulan data dapat dilihat pada tabel berikut ini:

Jenis instrumen yang digunakan pada saat pengumpulan data

\begin{tabular}{|c|c|c|c|}
\hline No & Jenis Metode & Langkah Penelitian & Jenis Intrumen \\
\hline 1. & Observasi & $\begin{array}{l}\text { Peneliti melakukan pengamatan di } \\
\text { sekolah melihat permasalahan yang ada. }\end{array}$ & $\begin{array}{l}\text { Catatan lapangan } \\
\text { Lembar pengamatan }\end{array}$ \\
\hline 2. & $\begin{array}{l}\text { Interviu atau } \\
\text { Wawancara }\end{array}$ & $\begin{array}{l}\text { Peneliti melakukan tanya jawab kepada } \\
\text { guru penjasorkes yang ada di sekolah. }\end{array}$ & Daftar pertanyaan \\
\hline \multirow[t]{2}{*}{3.} & \multirow[t]{2}{*}{$\begin{array}{l}\text { Angket atau } \\
\text { Kuesioner }\end{array}$} & $\begin{array}{l}\text { Peneliti memberikan } \\
\text { pertanyaan kepada ahli pembelajaran } \\
\text { atletik, dan ahli media pembelajaran } \\
\text { mengenai produk yang dikembangkan. }\end{array}$ & Angket Semi Terbuka \\
\hline & & $\begin{array}{l}\text { Peneliti memberikan sejumlah } \\
\text { pertanyaan kepada siswa kelas VII } \\
\text { mengenai produk yang dikembangkan. }\end{array}$ & Angket Tertutup \\
\hline
\end{tabular}

Proses penelitian ini melibatkan dua ahli yakni ahli pembelajaran atletik divalidasi oleh bapak Muhammad Soleh Fudin, M. Pd. sebagai dosen mata kuliah atletik prodi penjas STKIP PGRI Trenggalek dan ahli media pembelajaran divalidasi oleh bapak Khamim Hariyadi, M. Pd. sebagai dosen mata kuliah perencanaan pembelajaran olahraga prodi penjas STKIP PGRI Trenggalek. Proses validasi desain produk ini berguna untuk memvalidasi desain produk yang dikembangkan guna menjaga kualitas produk yang dikembangkan dengan cara memberikan angket atau kuesioner semi terbuka: yang sudah disediakan jawabannya kemudian diikuti pertanyaan terbuka.. Pengujian media pembelajaran tolak peluru di uji cobakan dalam uji coba kelompok kecil sejumlah 14 subjek penelitian dan uji coba kelompok besar sejumlah 28 subjek penelitian pada siswa kelas VII SMP Negeri 1 Tugu untuk mengecek produk yang dikembangkan dengan cara memberikan angket tertutup: yang sudah disediakan jawabannya sehingga responden tinggal memilih.

Data yang diperoleh dari penelitian ini berupa data kualitatif dan kuantitatif. Data kualitatif diperoleh dari analisis kebutuhan dan proses validasi produk oleh para ahli sedangkan data kuantitatif diperoleh dari hasil uji coba kelompok kecil dan uji coba kelompok besar. Data kuantitatif yang diperoleh dari penelitian ini berupa persentase 
sederhana. Penggunaan teknik analisis data disesuaikan dengan tahap-tahap penelitian yang dilalui oleh peneliti. Berikut ini tahapan teknik analisis data yang digunakan dalam penelitian: 
Teknik Analisis Data yang Digunakan

\begin{tabular}{ccc}
\hline No & Tahap Penelitian & Jenis Teknik Analisis Data \\
\hline $\mathbf{1}$ & Analisis kebutuhan & Teknik analisis data kualitatif \\
$\mathbf{2}$ & Validasi desain produk & Teknik analisis data kualitatif \\
$\mathbf{3}$ & Uji coba kelompok kecil & Teknik analisis data kualitatif \\
& & Teknik analisis data kuantitatif \\
$\mathbf{4}$ & Uji coba kelompok besar & Teknik analisis data kualitatif \\
& & Teknik analisis data kuantitatif \\
\hline
\end{tabular}

Teknik analisis data kualitatif yang digunakan dalam penelitian ini adalah teknik analisis data model Miles dan Huberman. (Sugiyono, 2011) Berikut langkah-langkah yang terdapat dalam model Miles dan Huberman yang terdiri dari 3 langkah, yaitu: (1) Data reduction; Mereduksi data berarti merangkum, memilih hal-hal yang pokok, memfokuskan pada hal-hal yang penting, dicari tema dan polanya. (2) Data display; Dalam penelitian kualitatif, penyajian data bisa dilakukan dalam bentuk uraian singkat, bagan, hubungan antar kategori, flowchart dan sejenisnya. (3) Data Conclusion drawing; Kesimpulan awal yang dikemukakan masih bersifat sementara dan akan berubah bila tidak ditemukan buktibukti yang kuat yang mendukung pada tahap pengumpulan data berikutnya.

Teknik analisis data kuantitatif yang digunakan dalam penelitian dan pengembangan ini berupa teknik analisis diskriptif, data dalam bentuk persentase yang digunakan untuk menganalisis hasil pengumpulan data uji coba kelompok kecil dan uji coba kelompok besar. Rumus untuk mengolah data yang berupa deskriptif persentase (Sudijono, 2014:43) adalah sebagai berikut:

$$
P=\frac{F}{N} \times 100 \%
$$

Keterangan: $(F)$ : Frekuensi yang sedang dicari persentasenya, $(\mathrm{N})$ : Number of case (jumlah frekuensi dari banyaknya individu), (P): Angka persentase. Apabila datanya berupa persentase, proporsi maupun rasio, maka kesimpulan dapat diambil, disesuaikan dengan permasalahannya. (Arikunto, 2013) Berikut ini penggolongan persentase kategori yang akan digunakan adalah: (1) Persentase kategori baik; 76\% - 100\% digunakan, (2) Persentase kategori cukup; 56\% - 75\% digunakan, (3) Persentase kategori kurang baik; 40\% - 55\% tidak digunakan, (4) Persentase kategori tidak baik; < $40 \%$ tidak digunakan. 


\section{HASIL DAN PEMBAHASAN}

Dari hasil observasi yang dilakukan di SMP Negeri 1 Tugu sarana dan prasarana yang ada untuk cabang olahraga atletik nomor tolak peluru belum memadai, jumlah peluru hanya ada 6 buah peluru dan untuk lapangan tolak peluru belum ada sebagai pengganti ada lapangan bola voli yang beralaskan tanah. Terkait dengan adanya permasalahan di atas untuk pembelajaran cabang olahraga atletik nomor tolak peluru jarang dipraktekkan karena tidak mempunyai media lain yang dapat dijadikan sebagai alternatif media pembelajaran tolak peluru. Hasil wawancara dengan guru penjasorkes di SMP Negeri 1 Tugu adalah untuk pembelajaran cabang olahraga atletik nomor tolak peluru mengalami permasalan bahwa jumlah peluru di sekolah tidak mencukupi untuk melaksanakan pembelajaran yang ideal. Kendala ini bisa dilihat dari sekian banyak siswa yakni dari kelas VII sampai kelas IX yang berjumlah 600 siswa hanya mempunyai 6 buah peluru yakni 3 buah peluru untuk kategori putra dan 3 buah untuk kategori putri, akibat dari permasalahan ini siswa di SMP Negeri 1 Tugu jarang melaksanakan praktek pembelajaran cabang olahraga atletik nomor tolak peluru karena pembelajaran tidak maksimal.

Uji coba kelompok kecil dilakukan peneliti di SMP Negeri 1 Tugu dengan 14 subjek penelitian. Hasil dari uji coba kelompok kecil dengan nilai rata-rata 82\% (kategori baik) media pembelajaran tolak peluru dapat digunakan sebagai alternatif media pembelajaran tolak peluru dan dapat dilanjutkan pada uji coba kelompok besar. Uji coba kelompok besar dilakukan peneliti di SMP Negeri 1 Tugu dengan 28 subjek penelitian. Hasil dari uji coba kelompok besar Hasil dari uji coba kelompok besar dengan nilai rata-rata 82,71\% (kategori baik) media pembelajaran tolak peluru dapat digunakan sebagai alternatif media pembelajaran tolak peluru dan tidak perlu melakukan revisi. Berikut ini tabel hasil uji coba kelompok kecil dan hasil uji coba kelompok besar:

Hasil Uji Coba Kelompok Kecil

\begin{tabular}{clccc}
\hline No & \multicolumn{1}{c}{ Aspek Yang Ditanyakan } & Persentase & Kategori & Simpulan \\
\hline $\mathbf{1}$ & Kemudahan penggunaan & $81,43 \%$ & Baik & Dapat digunakan \\
$\mathbf{2}$ & Kemenarikan bentuk media & $78,57 \%$ & Baik & Dapat digunakan \\
$\mathbf{3}$ & Kerapian bentuk media & $78,57 \%$ & Baik & Dapat digunakan \\
$\mathbf{4}$ & Keamanan media ketika digunakan & $84,29 \%$ & Baik & Dapat digunakan \\
$\mathbf{5}$ & Kenyamanan media ketika digu- & $90 \%$ & Baik & Dapat digunakan \\
& nakan & & & \\
$\mathbf{6}$ & Kemenarikan warna & $88,57 \%$ & Baik & Dapat digunakan \\
$\mathbf{7}$ & Kesesuaian diameter peluru & $84,29 \%$ & Baik & Dapat digunakan \\
$\mathbf{8}$ & Tekstur media & $75,71 \%$ & Cukup & Dapat digunakan \\
$\mathbf{9}$ & Kemiripan media dengan yang asli & $80 \%$ & Baik & Dapat digunakan \\
$\mathbf{1 0}$ & Tingkat kesukaan & & & \\
\hline
\end{tabular}




\begin{tabular}{llccc}
\hline $\mathbf{1 1}$ & Tingkat kesenangan & $82,86 \%$ & Baik & Dapat digunakan \\
$\mathbf{1 2}$ & $\begin{array}{l}\text { Perbandingan tingkat } \\
\text { dengan media yang asli }\end{array}$ & $75,71 \%$ & Cukup & Dapat digunakan \\
$\mathbf{1 3}$ & Mempermudah pembelajaran & $82,86 \%$ & Baik & Dapat digunakan \\
$\mathbf{1 4}$ & Tingkat minat siswa & $80 \%$ & Baik & Dapat digunakan \\
$\mathbf{1 5}$ & Tingkat kesulitan & $82,86 \%$ & Baik & Dapat digunakan \\
$\mathbf{1 6}$ & $\begin{array}{l}\text { Dapat dijadikan sebagai pengganti } \\
\text { media yang asli }\end{array}$ & $77,14 \%$ & Baik & Dapat digunakan \\
\hline
\end{tabular}

Hasil Uji Coba Kelompok Besar

\begin{tabular}{clccc}
\hline No & \multicolumn{1}{c}{ Aspek Yang Ditanyakan } & Persentase & Kategori & Simpulan \\
\hline $\mathbf{1}$ & Kemudahan penggunaan & $78,57 \%$ & Baik & Dapat digunakan \\
$\mathbf{2}$ & Kemenarikan bentuk media & $90 \%$ & Baik & Dapat digunakan \\
$\mathbf{3}$ & Kerapian bentuk media & $77,86 \%$ & Baik & Dapat digunakan \\
$\mathbf{4}$ & Keamanan media ketika digunakan & $85,71 \%$ & Baik & Dapat digunakan \\
$\mathbf{5}$ & Kenyamanan media ketika digu- & $82,14 \%$ & Baik & Dapat digunakan \\
& nakan & $77,86 \%$ & Baik & Dapat digunakan \\
$\mathbf{6}$ & Kemenarikan warna & $82,86 \%$ & Baik & Dapat digunakan \\
$\mathbf{7}$ & Kesesuaian diameter peluru & $83,57 \%$ & Baik & Dapat digunakan \\
$\mathbf{8}$ & Tekstur media & $81,43 \%$ & Baik & Dapat digunakan \\
$\mathbf{9}$ & Kemiripan media dengan yang asli & $80 \%$ & Baik & Dapat digunakan \\
$\mathbf{1 0}$ & Tingkat kesukaan & $76,43 \%$ & Baik & Dapat digunakan \\
$\mathbf{1 1}$ & Tingkat kesenangan & $81,43 \%$ & Baik & Dapat digunakan \\
$\mathbf{1 2}$ & Perbandingan tingkat kesukaan & & \\
& dengan media yang asli & $91,43 \%$ & Baik & Dapat digunakan \\
$\mathbf{1 3}$ & Mempermudah pembelajaran & $82,14 \%$ & Baik & Dapat digunakan \\
$\mathbf{1 4}$ & Tingkat minat siswa & $89,29 \%$ & Baik & Dapat digunakan \\
$\mathbf{1 5}$ & Tingkat kesulitan & $82,86 \%$ & Baik & Dapat digunakan \\
$\mathbf{1 6}$ & Dapat dijadikan sebagai pengganti & & & \\
\hline & media yang asli & &
\end{tabular}

Hasil pengembangan desain produk media pembelajaran tolak peluru mengalami perubahan berdasarkan pada hal-hal yang disarankan oleh ahli pada proses validasi produk. Pada proses validasi produk peneliti menunjuk 2 ahli untuk memvalidasi produk yang dikembangkan. Ahli yang bertindak sebagai validator adalah ahli dalam bidang pembelajaran atletik dan ahli dalam bidang media pembelajaran. Pada proses pengembangan desain media peneliti menambahkan beberapa hal pada media yang dikembangkan. Tambahan yang terdapat pada media berdasar pada saran-saran yang diberikan oleh para ahli. Pada awalnya desain media hanya berwarna hijau, alur benang tidak teratur, dan lapisan bagian luar teksturnya kasar, setelah ditambahkan beberapa hal yang didasarkan pada saran-saran yang diberikan oleh ahli maka desain produk mengalami perubahan. Berikut ini gambar perubahan produk awal dan sesudah mendapatkan saran dari ahli pembelajaran atletik dan ahli media pembelajaran pada saat validasi desain produk: 

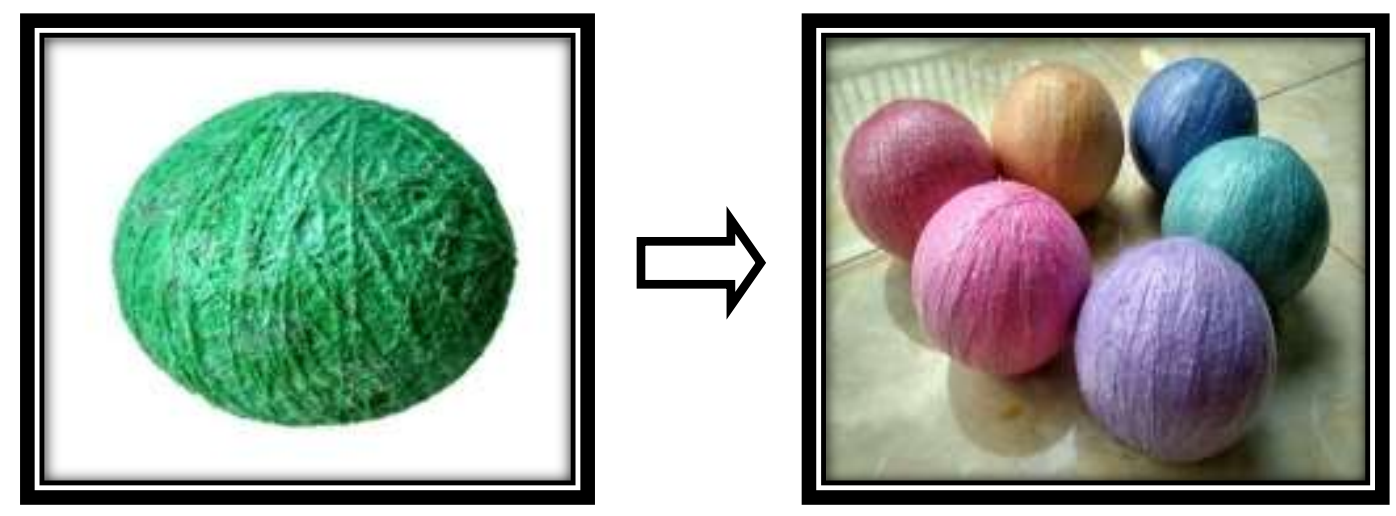

Desain Awal

Desain Setelah Validasi

Gambar

Perubahan Desain pada Media

\section{SIMPULAN DAN SARAN}

Simpulan dari seluruh proses penelitian menyatakan bahwa dari hasil observasi di SMP Negeri 1 tugu dapat disimpulkan bahwa sarana dan prasarana yang ada tidak mendukung untuk melaksanakan pembelajaran tolak peluru. Dari hasil wawancara dapat disimpulkan bahwa media pembelajaran tolak peluru yang ada di sekolah tidak mencukupi untuk melaksanakan pembelajaran yang ideal. Berdasarkan hasil dari proses validasi desain dengan ahli pembelajaran atletik dan ahli media pembelajaran dapat disimpulkan bahwa media mengalami perubahan. Perubahan dilakukan guna memperbaiki media agar warnanya lebih menarik, medianya awet, bentuk media lebih rapi, dan lebih mudah digunakan oleh siswa saat di uji cobakan. Perubahan-perubahan yang ada pada media pembelajaran tolak peluru merupakan saran dari kedua ahli. Hasil dari uji coba kelompok kecil dan uji coba kelompok besar dapat disimpulkan bahwa media pembelajaran tolak peluru dapat digunakan sebagai alternatif media pembelajaran tolak peluru di SMP Negeri 1 Tugu pada siswa kelas VII berdasarkan hasil persentase yang diperoleh dari hasil uji coba kelompok kecil dan dari hasil uji coba kelompok besar. Kelebihan dari media yang dikembangkan adalah: (1) Berat lebih ringan, (2) Bentuk media rapi, (3) Variasi warna media menarik, (4) Hasil produk bulat.

Saran yang bisa peneliti sampaikan ada tiga yakni; (1) Bagi guru penjasorkes di SMP Negeri 1 Tugu; diharapkan dapat mengembangkan media lain dalam pembelajaran penjasorkes yang lebih menarik untuk mempermudah penyampaian materi pembelajaran penjasorkes di sekolah, (2) Bagi siswa; harus dapat menggunakan media dengan baik dan 
bijak, walaupun media yang dikembangkan berat lebih ringan jangan dibuat mainan dengan cara hanya dilempar-lempar, harus digunakan sesuai dengan kegunaan dan fungsinya, (3) Bagi peneliti lain; yang ingin mengembangkan media sejenis atau melanjutkan pengembangan media pembelajaran tolak peluru sebaiknya mengetahui berapa lama ketahanan peluru yang digunakan dan mengetahui bagaimana cara mempertahankan kepadatan peluru supaya lebih awet.

\section{UCAPAN TERIMA KASIH}

Bapak Yudi Setiyono, SH., M.H. selaku Ketua STKIP PGRI Trenggalek. Bapak Henri Gunawan Pratama, M.Pd. selaku Ketua Jurusan Prodi Pendidikan Jasmani STKIP PGRI Trenggalek. Bapak Baskoro Nugroho Putro, M.Pd. selaku Dosen pembimbing 1 yang telah meluangkan waktu dan tenaga untuk memberikan bimbingan dalam penyusunan artikel skripsi ini. Bapak Wawan Prasetyo, M.Pd. selaku Dosen pembimbing 2 yang telah meluangkan waktu dan tenaga untuk memberikan bimbingan dalam penyusunan artikel skripsi ini. Seluruh Dosen PENJAS STKIP PGRI Trenggalek atas ilmu, bimbingan, arahan, nasihat, dan motivasi selama penulis belajar di STKIP PGRI Trenggalek. Kepala Kesbangpol Kabupaten Trenggalek yang telah memberikan izin penelitian di SMP Negeri 1 Tugu. Kepala Dinas Pendidikan Pemuda dan Olahraga yang telah memberikan izin penelitian di SMP Negeri 1 Tugu. Kepala SMP Negeri 1 Tugu yang telah memberikan izin untuk mengadakan penelitian di sekolah yang dipimpin. Siswa kelas VII SMP Negeri 1 Tugu yang telah bersedia menjadi sampel penelitian. Kedua orang tua, sahabat, dan temanteman seperjuangan PENJAS T.A 2014 yang telah membantu memberikan doa serta motivasi kepada penulis sehingga dapat menyelsaikan artikel skripsi ini dan semua pihak yang telah banyak membantu dalam penyusunan skripsi ini.

\section{DAFTAR RUJUKAN}

Arikunto, S. 2013. Prosedur Penelitian: Suatu Pendekatan Praktek. Jakarta: Rineka Cipta.

Branch, M.R. 2009. Instructional Design: The ADDIE Approach. New York: Springer Science \& Business Media.

Pardijono dan Yulfadinata, A. 2014. Buku Ajar Sarana dan Prasarana Olahraga. Surabaya: Unesa University Press.

Putro, B. N. (2016). PENGEMBANGAN MEDIA PEMBELAJARAN KETERAMPILAN GERAK DASAR UNTUK ANAK USIA DINI. BRAVO'S (Jurnal Prodi Pendidikan Jasmani \& Kesehatan), 4(2).

Putro, B. N. (2016). PENGEMBANGAN MODEL PEMBELAJARAN KETRAMPILAN GERAK DASAR MENGGUNAKAN MEDIA CONE DAN BOLA WARNAWARNI. Karya Ilmiah Dosen, 2(1). 
Sudijono, A. 2014. Pengantar Statistik Pendidikan. Jakarta: Grafindo Persada.

Sugiyono. 2011. Metode Penelitian Kuantitatif, Kualtitatif dan R \& D. Bandung: Alfabeta.

Umbara, C. 2017. Undang - Undang RI No. 20 tahun 2003 tentang SISDIKNAS \& Peraturan Pemerintah RI Tahun 2015 tentang Standar Nasional Pendidikan Serta Wajib Belajar. Bandung: Citra Umbara

Wirto, G. 2015. Inovasi Pembelajaran dalam Pendidikan Jasmani. Yogyakarta: Laksitas. 